\title{
Gambaran Komplikasi Transurethral Resection of the Prostate pada Pasien Benign Prostatic Hyperplasia
}

\author{
Zuhirman $^{1 *}$, Desby Juananda ${ }^{2}$, Putry Lestari ${ }^{3}$
}

\begin{abstract}
Benign prostatic hyperplasia (BPH) is a benign tumor that most common, a serious problem and may affect the quality of life. Transurethral resection of the prostate (TURP) is the gold standard for BPH management. The aim of this study was to describe the complications of TURP in patients with BPH. This was a descriptive study by reviewing the medical records of BPH patients underwent TURPs at RSUD Arifin Achmad, Riau Province in 2011-2015. There were 280 medical records fulfilled the inclusion criteria in which showed 93 patients who experienced complications of TURP. The most age range was 60-69 years old (12,9\%), the mean of the resection duration was 30(10-80) minutes and the mean of weight of the resected prostatic tissue was $30(10-50)$ grams. The most common complications was bleeding $(42,9 \%)$, urinary retention $(27,6 \%)$.In the research, we conclude the complications were higher than the ones in the literatures.
\end{abstract}

Keywords : BPH, TURP, complications of TURP

Hiperplasia prostat jinak atau dikenal sebagai benign prostatic hyperplasia $(\mathrm{BPH})$ merupakan tumor jinak yang paling sering terjadi pada pria. ${ }^{1}$ Hampir 30 juta pria di dunia menderita BPH dan di Amerika Serikat hampir 14 juta pria menderita $\mathrm{BPH}^{2-3}$ Benign prostatic hyperplasia merupakan penyakit tersering kedua setelah batu saluran kemih di Indonesia. Sebanyak 423 kasus BPH ditemukan di RS Cipto Mangunkusumo (RSCM) pada tahun 1994-1997 dan di RS Sumber Waras Jakarta ditemukan sebanyak 617 kasus pada tahun yang sama. Kasus BPH Pekanbaru merupakan kasus yang tersering di bagian urologi. Hal ini dilihat dari jumlah kasus BPH di RSUD Arifin Achmad Provinsi Riau yaitu 456 kasus pada tahun 2011-2014. ${ }^{4}$

Benign prostate hiperplasia mempengaruhi kualitas hidup pada pria usia lanjut sehingga $\mathrm{BPH}$ harus ditatalaksana dengan tepat. Pilihan baku emas untuk tatalaksana BPH adalah transurethral

\footnotetext{
${ }^{1 *}$ Penulis untuk korespondensi KJF Bedah Divisi Urologi FK Universitas Riau.RSUD Arifin Achmad Jalan Diponegoro No.1, Pekanbaru. Email correspondence:zuhirman.zamzami@yahoo.com

2 Bagian Anatomi:FK Universitas Riau.

3 Putry Lestari: Mahasiswa FK Universitas Riau
}

resection prostatic (TURP). ${ }^{1,5-8}$ Data di Amerika Serikat menunjukkan bahwa dilakukan TURP sekitar 300.000 kali setiap tahunnya, ${ }^{7}$ sedangkan di Indonesia datanya belum dipublikasikan dengan lengkap. Data dari RSUD Arifin Achmad Provinsi Riau pada tahun 2009 - 2010 terdapat 122 kasus BPH yang telah menjalani TURP. ${ }^{9}$

Kelebihan TURP dibanding tindakan invasif lain adalah lebih singkatnya perawatan di rumah sakit, keunggulan dalam perbaikan gejala berdasarkan International Prostate Symptom Score (IPSS), komplikasi yang minimal, dan perbaikan laju aliran urin. ${ }^{1}$ Penelitian melaporkan terjadi perbaikan indeks berat gejala berdasarkan American Urological Association (AUA) sebesar 70-85\% pada $80-90 \%$ kasus. ${ }^{10}$ Penelitian melaporkan tingkat keberhasilan TURP sebesar $81 \%$ dibandingkan dengan terapi laser sebesar $67 \%$ dan terapi konservatif sebesar $15 \%$. $^{7}$

Meskipun TURP menjadi pilihan utama pada terapi $\mathrm{BPH}$, kemungkinan terjadinya komplikasi tidak dapat dihindari ${ }^{11}$ yaitu intraoperatif, perioperatif dan lanjut. Komplikasi intraoperatif meliputi perdarahan, perforasi buli, perforasi kapsul prostat, sindroma TUR dan kematian. Komplikasi perioperatif meliputi perdarahan, retensi urin, 
infeksi saluran kemih, epididimitis, clot retention dan kematian. Komplikasi lanjut meliputi striktur urethra, retensi urin berulang, inkontinensia urin, ejakulasi retrograd,dan disfungsi ereksi. ${ }^{6}$

Komplikasi intraoperatif yang paling berat adalah sindroma TUR dengan angka mortalitas sebesar $0,99 \% .{ }^{6}$ Komplikasi perdarahan dapat terjadi, baik selama maupun setelah operasi yang pada umumnya membutuhkan tindakan transfusi sekitar $4 \%$ pasien yang menjalani TURP. ${ }^{12}$ Komplikasi pascaoperasi yang paling sering adalah retensi urin sebanyak 24\%. ${ }^{12}$ Angka kejadian komplikasi lanjut meliputi ejakulasi retrograd sebesar $75 \%$, disfungsi ereksi sebesar 5-10\% dan inkontinensia $<1 \%$. ${ }^{1}$

Penelitian mengenai komplikasi tindakan TURP di Pekanbaru belum pernah dilakukan, tetapi penelitian mengenai karakteristik pasien $\mathrm{BPH}$ yang menjalani TURP di RSUD Arifin Achmad telah dilakukan tetapi tidak ada penjelasan mengenai komplikasi tindakan TURP. ${ }^{9}$ Berdasarkan uraian tersebut, peneliti tertarik untuk mengetahui gambaran komplikasi pasien BPH pasca tindakan TURP di RSUD Arifin Achmad Provinsi Riau.

Tujuan penelitian ini untuk mengetahui gambaran komplikasi tindakan TURP pada pasien BPH di RSUD Arifin Achmad Provinsi Riau

\section{METODE}

Penelitian ini bersifat deskriptif. Datanya diperoleh dari rekam medis pasien BPH yang menjalani TURP di RSUD Arifin Achmad Propinsi Riau periode Januari 2011 hingga Desember 2015.

Sampel penelitian ini adalah semua pasien BPH yang menjalani TURP di RSUD Arifin Achmad Propinsi Riau periode Januari 2011 hingga Desember 2015 yang memenuhi kriteria inklusi. Kriteria inklusi pada penelitian ini yaitu pasien BPH berdasarkan hasil pemeriksaan histopatologi dan menjalani TURP dengan data rekam medis yang terdapat hasil laboratorium darah rutin dan elektrolit. Kriteria eksklusinya adalah pasien BPH yang menjalani TURP disertai dengan pembedahan urologi lainnya seperti sectio alta, bladder neck incision, lithotripsy, sachse, TUR buli, vesicolithotripsy, meatotomy, dan TUR bladder neck. Variabel penelitian adalah umur, durasi reseksi, berat chip prostat, komplikasi intraoperatif, komplikasi perioperatif dan komplikasi lanjut

\section{HASIL}

Pada penelitian ini didapatkan 280 pasien BPH yang menjalani tindakan TURP dan didapatkan sebanyak 105 kasus komplikasi pada 93 pasien.

\section{Distribusi Tindakan TURP Berdasarkan Tahun di RSUD Arifin Achmad Provinsi Riau periode tahun 2011-2015}

Distribusi tindakan TURP berdasarkan tahun dapat dilihat pada tabel 1 berikut:

Tabel 1. Jumlah tindakan TURP pada pasien BPH di RSUD Arifin Achmad Provinsi Riau periode tahun 2011-2015

\begin{tabular}{ccc}
\hline Tahun & Frekuensi (N) & Persentase (\%) \\
\hline 2011 & 56 & 20 \\
2012 & 55 & 19,6 \\
2013 & 71 & 25,4 \\
2014 & 65 & 23,2 \\
2015 & 33 & 11,8 \\
\hline Jumlah & 280 & 100 \\
\hline
\end{tabular}


Tabel 1 menunjukkan bahwa tindakan TURP pada pasien BPH paling banyak dilakukan pada tahun 2013 yaitu 71 pasien $(25,4 \%)$ dan paling sedikit pada tahun 2015 yaitu sebanyak 33 pasien $(11,8 \%)$. Rata-rata tindakan TURP dilakukan tiap tahunnya sebanyak 56 pasien.
Distribusi Kejadian Komplikasi TURP di RSUD Arifin Achmad Provinsi Riau periode tahun 2011-2015

Distribusi tindakan TURP tanpa komplikasi dan dengan komplikasi dapat dilihat pada tabel 2.

Tabel 2. Distribusi tindakan TURP pada pasien BPH di RSUD Arifin Achmad Provinsi Riau periode tahun 2011-2015

\begin{tabular}{ccc}
\hline Tindakan TURP & Frekuensi (N) & Persentase (\%) \\
\hline Tanpa komplikasi & 187 & 66,8 \\
Dengan komplikasi & 93 & 33,2 \\
\hline Jumlah & $\mathbf{2 8 0}$ & $\mathbf{1 0 0}$ \\
\hline
\end{tabular}

Tabel 2 tersebut menunjukkan bahwa dari 271 pasien BPH yang menjalani tindakan TURP sebanyak 93 pasien $(33,2 \%)$ dengan gejala komplikasi. Distribusi kejadian komplikasi TURP berdasarkan tahun dapat dilihat pada tabel 3 berikut:

Tabel 3. Distribusi kejadian komplikasi TURP berdasarkan tahun di RSUD Arifin Achmad Provinsi Riau periode tahun 2011-2015

\begin{tabular}{ccc}
\hline Tahun & Frekuensi $\mathbf{( N )}$ & Persentase (\%) \\
\hline 2011 & 19 & 18,1 \\
2012 & 21 & 20,0 \\
2013 & 28 & 26,7 \\
2014 & 22 & 21,0 \\
2015 & 15 & 14,2 \\
\hline Jumlah & 105 & 100 \\
\hline
\end{tabular}

Tabel 3 menunjukkan bahwa komplikasi TURP pada pasien BPH paling banyak terjadi pada tahun 2013 yaitu 28 kasus $(26,7 \%)$ dan paling sedikit pada tahun 2015 yaitu sebanyak 15 kasus (14,2\%). Ratarata kejadian komplikasi TURP tiap tahun adalah sebanyak 21 kasus.
Gambaran Kelompok Usia Pasien BPH yang Menjalani TURP dengan Komplikasi di RSUD Arifin Achmad Provinsi Riau periode tahun 2011-2015

Distribusi faktor risiko timbulnya komplikasi TURP berdasarkan usia dapat dilihat pada tabel 4 .

Tabel 4. Kelompok usia pasien BPH yang menjalani TURP dengan komplikasi di RSUD Arifin Achmad Provinsi Riau periode tahun 2011-2015

\begin{tabular}{cccc}
\hline \multirow{2}{*}{ Umur } & \multicolumn{2}{c}{ Tindakan TURP } & \multirow{2}{*}{ Jumlah } \\
\cline { 2 - 3 } & Dengan komplikasi & Tanpa komplikasi & \\
\cline { 2 - 3 } & $\mathbf{N}(\mathbf{\%})$ & $\mathbf{N}(\mathbf{\%})$ & $\mathbf{N}(\mathbf{\%})$ \\
\hline $40-49$ tahun & $2(0,8)$ & $6(2,1)$ & $8(2,9)$ \\
$50-59$ tahun & $17(6,1)$ & $37(13,2)$ & $54(19,3)$ \\
$60-69$ tahun & $39(13,9)$ & $69(24,7)$ & $108(38,6)$ \\
$70-79$ tahun & $28(9,9)$ & $62(22,2)$ & $90(32,1)$ \\
$>80$ tahun & $7(2,5)$ & $13(4,6)$ & $20(7,1)$ \\
\hline Jumlah & $\mathbf{9 3}(\mathbf{3 3 , 2})$ & $\mathbf{1 8 7}(\mathbf{6 6 , 8})$ & $\mathbf{2 8 0}(\mathbf{1 0 0})$ \\
\hline
\end{tabular}


Berdasarkan tabel 4 dapat dilihat bahwa kelompok usia pasien BPH yang menjalani TURP terbanyak adalah pada usia 60-69 tahun yaitu 108 pasien $(38,6 \%)$. Kelompok usia pasien BPH yang menjalani TURP dengan komplikasi terbanyak adalah pada usia 60-69 tahun yaitu 39 pasien $(13,9 \%)$.
Gambaran Durasi Reseksi TURP pada pasien BPH di RSUD Arifin Achmad Provinsi Riau periode tahun 2011-2015

Distribusi faktor risiko timbulnya komplikasi TURP berdasarkan durasi reseksi dapat dilihat pada tabel 5.

Tabel 5. Durasi reseksi TURP pada pasien BPH di RSUD Arifin Achmad Provinsi Riau periode tahun 2011-2015

\begin{tabular}{cccc}
\hline \multirow{2}{*}{$\begin{array}{c}\text { Durasi } \\
\text { reseksi }\end{array}$} & \multicolumn{2}{c}{ Tindakan TURP } & Jumlah \\
\cline { 2 - 4 } & $\begin{array}{c}\text { Dengan } \\
\text { komplikasi }\end{array}$ & $\begin{array}{c}\text { Tanpa } \\
\text { komplikasi }\end{array}$ & $\mathrm{n}$ \\
\cline { 2 - 4 } 10 menit & 1 & $\mathrm{n}$ & 6 \\
15 menit & 8 & 19 & 27 \\
20 menit & 14 & 33 & 47 \\
25 menit & 1 & 7 & 8 \\
30 menit & 16 & 15 & 31 \\
35 menit & 12 & 27 & 39 \\
40 menit & 2 & 9 & 11 \\
45 menit & 0 & 4 & 4 \\
50 menit & 16 & 37 & 53 \\
55 menit & 1 & 1 & 2 \\
65 menit & 4 & 4 & 8 \\
80 menit & 2 & 1 & 3 \\
Tidak ada data & 16 & 25 & 41 \\
\hline Jumlah & $\mathbf{9 3}$ & $\mathbf{1 8 7}$ & $\mathbf{2 8 0}$ \\
\hline
\end{tabular}

Berdasarkan tabel 5 diperoleh bahwa rerata durasi reseksi pada pasien BPH yang menjalani TURP yaitu 35 (10-80) menit, sedangkan rerata durasi reseksi TURP pada pasien BPH yang mengalami komplikasi yaitu 30 (10-80) menit.
Gambaran Berat Jaringan Prostat yang Direseksi (chip prostat) pada Pasien BPH yang Menjalani TURP di RSUD Arifin Achmad Provinsi Riau periode tahun 2011-2015

Distribusi faktor risiko timbulnya komplikasi TURP berdasarkan berat chip prostat dapat dilihat pada tabel 6. 
Tabel 6. Berat chip prostat pada pasien BPH yang menjalani tindakan TURP di RSUD Arifin Achmad Provinsi Riau periode tahun 2011-2015

\begin{tabular}{lccc}
\hline \multirow{2}{*}{$\begin{array}{c}\text { Berat } \text { chip } \\
\text { prostat }\end{array}$} & \multicolumn{2}{c}{ Tindakan TURP } & Jumlah \\
\cline { 2 - 3 } & $\begin{array}{c}\text { Dengan } \\
\text { komplikasi }\end{array}$ & $\begin{array}{c}\text { Tanpa } \\
\text { komplikasi }\end{array}$ & \\
\cline { 2 - 3 } & $\mathbf{N}$ & $\mathbf{n}$ & $\mathbf{N}$ \\
\hline 10 gram & 7 & 17 & 24 \\
15 gram & 7 & 12 & 19 \\
20 gram & 19 & 57 & 64 \\
25 gram & 2 & 6 & 8 \\
30gram & 28 & 71 & 99 \\
40 gram & 4 & 4 & 8 \\
50 gram & 3 & 2 & 5 \\
Tidak ada data & 23 & 30 & 53 \\
\hline Jumlah & $\mathbf{9 3}$ & $\mathbf{1 8 7}$ & $\mathbf{2 8 0}$ \\
\hline
\end{tabular}

Berdasarkan tabel 6 dapat dilihat bahwa rerata berat jaringan prostat yang direseksi (chip prostat) pasien BPH yang menjalani TURP yaitu 25 (10-50) gram, sedangkan rerata berat jaringan prostat yang direseksi (chip prostat) pada pasien BPH yang menjalani TURP dengan komplikasi yaitu 30 (1050) gram.

Jenis Komplikasi TURP pada Pasien BPH di RSUD Arifin Achmad Provinsi Riau periode tahun 2011-2015

Tabel 7. Jenis komplikasi TURP pada pasien BPH di RSUD Arifin Achmad Provinsi Riau periode tahun 2011-2015

\begin{tabular}{lcc}
\hline \multicolumn{1}{c}{ Jenis komplikasi } & Frekuensi (n) & Persentase (\%) \\
\hline Komplikasi intraoperatif & 45 & 42,9 \\
a. Perdarahan & 0 & 0 \\
b. Perforasi buli & 0 & 0 \\
c. Perforasi kapsul prostat & 0 & 0 \\
d. Sindrom TURP & 0 & 0 \\
e. Meninggal & & 3,9 \\
Komplikasi perioperatif & 4 & 3,9 \\
a. Perdarahan & 4 & 0 \\
b. Infeksi saluran kemih & 0 & 4,8 \\
c. Epididimitis & 5 & 27,6 \\
d. Clot retention & 29 & 8,6 \\
e. Retensio urin & 9 & \\
f. Meninggal & & 2,6 \\
Komplikasi lanjut & 3 & 5,7 \\
a. Striktur uretra & 6 & 0 \\
b. Retensio urin & 0 & 0 \\
c. Inkontinensia urin & 0 & $\mathbf{1 0 0}$ \\
d. Disfungsi ereksi & 0 & \\
e. Ejakulasi retrogad & $\mathbf{1 0 5}$ & \\
\hline
\end{tabular}


Berdasarkan tabel 7, jumlah komplikasi yang paling tinggi adalah komplikasi intraoperatif yaitu perdarahan sebanyak 45 kasus $(42,9 \%)$. Jenis komplikasi intraoperatif yang paling sering adalah perdarahan yaitu 45 kasus (42,9\%). Jenis komplikasi perioperatif yang paling sering adalah retensi urin yaitu 29 kasus $(27,6 \%)$ dan jenis komplikasi lanjut yang paling sering adalah retensi urin yaitu 6 kasus $(5,7 \%)$.

\section{PEMBAHASAN}

Penelitian ini menggambarkan kejadian komplikasi TURP pada pasien BPH di RSUD Arifin Achmad Provinsi Riau periode tahun 2011-2015 dilihat dari angka kejadian berdasarkan kelompok usia, durasi reseksi, berat chip prostat, serta jenis komplikasi.

\section{Distribusi Pasien BPH yang Menjalani TURP di RSUD Arifin Achmad Provinsi Riau periode tahun 2011-2015}

Penelitian menunjukkan pasien BPH yang menjalani TURP mengalami kenaikan dan penurunan. Jumlah pasien yang menjalani TURP terbanyak pada tahun 2013 yaitu 71 pasien $(25,4 \%)$, sedangkan yang terendah berada pada tahun 2015 yaitu 33 pasien $(11,8 \%)$. Peningkatan jumlah tindakan TURP pada tahun 2013 karena terjadi penambahan ahli urologi di RSUD Arifin Achmad Provinsi Riau pada akhir tahun 2012 sehingga jadwal untuk operasinya lebih banyak. Penurunan tindakan TURP pada tahun 2015 terjadi perubahan pola penyakit tersering di bagian urologi. Data terdahulu menunjukkan BPH merupakan penyakit tersering namun sejak tahun 2014 mengalami penurunan dan bergeser menjadi batu saluran kemih. ${ }^{4}$

Distribusi Komplikasi pada Pasien BPH yang Menjalani TURP di RSUD Arifin Achmad Provinsi Riau periode tahun 2011-2015

Hasil penelitian menunjukkan dari 280 pasien BPH yang menjalani TURP terdapat 93 pasien $(33,2 \%)$ dengan komplikasi. Hasil penelitian ini lebih tinggi dibandingkan dengan penelitian yang dilakukan oleh Mamuolakis et al yang mendapatkan komplikasi sebanyak $15,7 \% \cdot{ }^{13} \mathrm{Hal}$ ini kemungkinan karena periode penelitian ini lebih lama dan jumlah sampel lebih banyak.

Selama periode 2011-2015, komplikasi TURP mengalami kenaikan dan penurunan, hal ini berbanding lurus dengan jumlah pasien BPH yang menjalani TURP. Jumlah komplikasi tertinggi tahun 2013 yaitu 28 kasus (26,7\%), sedangkan tahun 2015 sebanyak 15 kasus $(14,2 \%)$. Rendahnya jumlah kasus komplikasi pada tahun 2015 karena penurunan jumlah kasus BPH yang menjalani TURP di RSUD Arifin Achmad Provinsi Riau dari tahun-tahun sebelumnya atau adanya beberapa data yang tidak terkumpul. Penyebab lainnya karena perbaikan teknis TURP secara signifikan pada beberapa dekade terakhir seperti penggunaan instrumen yang fleksibel untuk meningkatkan visibilitas dan manuver loop reseksi. ${ }^{11}$

Gambaran Kelompok Usia Pasien BPH yang Menjalani TURP dengan Komplikasi di RSUD Arifin Achmad Provinsi Riau periode tahun 2011-2015

Hasil penelitian ini menunjukkan komplikasi yang terbanyak adalah kelompok usia 60-69 tahun $(13,9 \%)$ dan terendah pada kelompok usia 40-49 tahun $(0,7 \%)$ dan risiko komplikasi meningkat pada usia lanjut. Hal ini sesuai dengan penelitian Rassweiler yang menunjukkan komplikasi TURP meningkat $55 \%$ pada usia $>70$ tahun. ${ }^{11}$

Pria diatas 40 tahun akan mengalami penuaan dan penurunan kapasitas fungsional pada tingkat seluler dan tingkat organ. Penurunan kapasitas fungsional menyebabkan kurangnya respon terhadap berbagai rangsangan internal maupun eksternal, sehingga menyebabkan orang yang usia lanjut sulit untuk memelihara kestabilan status fisik dan kimiawi di dalam tubuh, atau memelihara homeostasis tubuh. Gangguan terhadap homeostasis tersebut menyebabkan disfungsi berbagai sistem organ dan toleransi terhadap obat-obatan menurun. ${ }^{14}$ Pada pasien dengan usia yang lebih tua terjadi peningkatan prevalensi penyakit penyerta sehingga dapat meningkatkan risiko komplikasi perioperatif. ${ }^{15}$ 


\section{Gambaran Durasi Reseksi TURP pada Pasien BPH di RSUD Arifin Achmad Provinsi Riau periode tahun 2011-2015}

Hasil penelitian menunjukkan rerata durasi reseksi TURP dengan komplikasi yaitu 30 (10-80) menit. Hasil ini lebih tinggi dibandingkan dengan penelitian yang dilakukan oleh Furaya et al yaitu 21,0 $\pm 13,5$ menit. ${ }^{16}$ Hasil penelitin ini lebih rendah dibandingkan hasil penelitian Berger yaitu 46 menit. ${ }^{11}$ Perbedaan hasil penelitian ini diduga disebabkan karena perbedaan teknik yang digunakan, dimana teknik ini tergantung pada keahlian dan pengalaman dari ahli urologi tersebut. ${ }^{11}$ Selain itu, durasi reseksi juga dipengaruhi volume prostat, dimana rata-rata kecepatan reseksi prostat adalah 1 gram/menit. ${ }^{11}$ Semakin besar ukuran prostatnya maka durasi reseksinya akan semakin lama.

Pada umumnya durasi reseksi TURP antara 3060 menit. ${ }^{16}$ Durasi reseksi yang lama (>70 menit) menjadi salah satu faktor risiko timbulnya komplikasi, ${ }^{11}$ terutama sindroma TUR. ${ }^{7}$ Sindroma TUR merupakan kumpulan tanda dan gejala yang disebabkan oleh penyerapan cairan hipotonik selama operasi endoskopi ${ }^{15}$ karena pembuluh darah vena prostat yang terbuka pada saat reseksi kapsul prostat. Jika durasi reseksinya lama maka cairan yang diirigasi secara terus menerus dapat menyebabkan cairan hiperosmolar masuk ke pembuluh darah dalam jumlah yang relatif besar, sehingga pasien akan mengalami hiponatremia ${ }^{7}$

Diperkirakan $20 \mathrm{ml}$ cairan irigasi diserap setiap menit durasi reseksi TURP. Penyerapan cairan yang berkepanjangan dapat menyebabkan hiperkalemia sementara. Pada awalnya terjadi hipertensi dan refleks bradikardi, namun sebagai sindrom yang terus berlangsung maka akan terjadi fase hemodinamik hipokinetik berupa hipotensi dan bradikardi serta penurunan curah jantung dan volume intravaskular. ${ }^{15}$

Durasi reseksi TURP tidak memiliki batasan yang mutlak yaitu 60 menit dan apabila lebih angka kejadian komplikasi menjadi lebih tinggi, diantaranya sindroma TUR, striktur urethra, sepsis, dan kehilangan darah yang berlebihan. ${ }^{15}$ Hasil penelitian ini menunjukkan durasi reseksi dalam batas normal sehingga diduga tidak berpengaruh terhadap timbulnya komplikasi TURP. Untuk itu, perlu dikaji lebih lanjut mengenai beberapa faktor risiko timbulnya komplikasi TURP.

\section{Gambaran Berat Jaringan Prostat yang Direseksi (chip prostat) pada Pasien BPH yang Menjalani TURP di RSUD Arifin Achmad Provinsi Riau periode tahun 2011-2015}

Hasil penelitian ini menunjukkan rerata berat chip prostat dengan komplikasi yaitu 30 (10-50) gram. Hasil ini lebih tinggi dibandingkan penelitian yang dilakukan oleh Furuya et al dengan rerata berat chip 17,0 $\pm 14,6$ gram. ${ }^{16}$ Penelitian oleh Rassweiler mendapatkan berat rerata chip prostat yaitu 29,3 gram. ${ }^{11}$ Penelitian oleh Berger memperoleh hasil yang lebih tinggi, yaitu 33 gram. ${ }^{11}$

Pada umumnya berat chip prostat itu bervariasi, mulai dari 5 gram sampai $>75$ gram dengan rata-rata 25 gram. ${ }^{18}$ Berat jaringan yang direseksi juga dapat menjadi faktor risiko komplikasi terutama komplikasi perdarahan jika berat jaringan yang direseksi melebihi 45 gram. Penelitian lain menyebutkan $85 \%$ pasien yang menjalani TURP memerlukan transfusi ketika berat jaringan yang direseksi melebihi 80 gram. ${ }^{19}$ Pasien BPH yang menjalani TURP diperkirakan akan mengalami kehilangan darah rata-rata $10-15 \mathrm{ml} /$ gram jaringan prostat yang direseksi ${ }^{20}$ sehingga diperkirakan semakin berat jaringan prostat yang direseksi maka pasien akan memiliki risiko yang lebih tinggi untuk mengalami kehilangan darah dalam jumlah yang besar.

\section{Jenis Komplikasi TURP pada Pasien BPH di RSUD Arifin Achmad Provinsi Riau periode tahun 2011-2015}

Hasil penelitian ini menunjukkan komplikasi intraoperatif yang terbanyak adalah perdarahan sebanyak 45 kasus $(42,9 \%)$ yang sesuai dengan penelitian Fajaruddin yaitu $16,1 \% .{ }^{21}$ Perdarahan ini dapat karena perdarahan arteri ataupun perdarahan vena terutama pada infeksi preoperatif atau retensi urin karena kelenjar yang padat sehingga menyebabkan peningkatan angiogenesis pada kelenjar prostat dan hal inilah yang menyebabkan risiko perdarahan. Perdarahan vena biasanya terjadi karena perforasi kapsul prostat atau vena sinusoid yang terbuka. ${ }^{11}$ 
Sumber perdarahan pada tindakan TURP ini dapat dikenali dari warna cairan irigasinya. Pada perdarahan arteri terjadi perubahan secara intermiten pada cairan irigasi dari jernih menjadi merah, sedangkan perdarahan vena menghasilkan cairan irigasi berwarna merah gelap. Jumlah perdarahan intraoperatif ini mungkin tergantung pada ukuran kelenjar prostat dan berat jaringan prostat yang direseksi. ${ }^{11}$

Komplikasi perioperatif yang tersering adalah retensi urin yaitu sebanyak 29 kasus $(27,6 \%)$. Hasil penelitian ini hampir sama dengan hasil penelitian Shreshta yaitu $24 \%{ }^{12}$ dan lebih tinggi dibandingkan dengan hasil penelitian Reich et al yaitu 5,8\%. ${ }^{22}$ Retensi urin ini terjadi karena kegagalan dalam kontraksi otot detrusor buli karena gangguan pada supravesika, yaitu kapasitas buli yang lebih besar dari normal yang terjadi pada pasien dengan penuaan buli dan distensi buli dalam waktu yang lama. ${ }^{23}$

Clot retention terjadi sebanyak 5 kasus $(4,8 \%)$. Hal ini sama dengan penelitian oleh Rassweiler et al yaitu $5 \%{ }^{11}$ dan penelitian oleh Fajaruddin yaitu 6,5\% ${ }^{21}$ Clot retention terjadi karena gumpalan darah pada kandung kemih sebagai akibat dari perdarahan yang resisten dapat menyebabkan oklusi pada irigasi kateter dan karena chip prostat yang tidak terekstraksi secara maksimal selama operasi. ${ }^{24}$

Jumlah pasien yang meninggal pada penelitian ini adalah sebanyak 9 pasien $(8,6 \%)$. Jumlah kasus ini diperoleh dari bagian rekam medik RSUD Arifin Achmad Provinsi Riau karena berkas rekam medik pasien tidak ditemukan. Hal ini menyebabkan peneliti tidak bisa menganalisa faktor yang dapat memperberat kondisi pasien sebelum meninggal dan juga tidak dapat diketahui waktu yang pasti pasien tersebut meninggal. Hasil penelitian ini lebih tinggi dibandingkan penelitian yang dilakukan oleh Fajaruddin yaitu 3,2\%. Pasien yang meninggal saat menjalani tindakan TURP diantara penyebabnya adalah sebagai akibat dari komplikasi sindroma TUR yang sulit diatasi. ${ }^{6}$ Selain itu, pasien yang meninggal setelah menjalani tindakan TURP biasanya timbul sebagai akibat dari komplikasi yang melibatkan jantung atau infeksi yang serius pascaoperasi. ${ }^{12}$

Infeksi saluran kemih terjadi sebanyak 4 kasus $(4,2 \%)$. Hasil penelitian ini lebih tinggi dibandingkan dengan penelitian oleh Rassweiler $e t$ al, yaitu terjadi $1,7 \%^{11}$ dan lebih rendah dibandingkan penelitian oleh Fajaruddin terjadi infeksi saluran kemih sebanyak 25,8\%. ${ }^{21}$ Hasil penelitian ini lebih tinggi dibandingkan penelitian Reich yaitu 3,6\%. ${ }^{22}$ Faktor risiko timbulnya infeksi saluran kemih pascaTURP ini adalah bakteriuria preoperatif, durasi operasi yang lebih lama (>70 menit), rawat inap preoperatif yang lebih dari dua hari, dan penghentian drainase kateter. Pada penelitian di Heilbronn kasus infeksi saluran kemih cukup rendah, yaitu $1,7 \%$ karena dilakukan pemeriksaan urinalisis rutin preoperatif untuk menyingkirkan infeksi saluran kemih yang tidak teratasi sebelum operasi. ${ }^{11}$

Jumlah kasus perdarahan pada komplikasi perioperatif adalah sebanyak 4 kasus $(4,2 \%)$. Hasil penelitian ini lebih tinggi dibandingkan dengan penelitian yang Furuya et at yaitu 2,4\%. ${ }^{16}$

Komplikasi lanjut yang tersering adalah retensi urin yaitu 6 kasus $(6,2 \%)$. Penyebab retensi urin adalah otot-otot yang berfungsi untuk mengontrol kandung kemih mengalami kerusakan sementara sehingga mengganggu proses pengosongan kandung kemih. ${ }^{25}$

Striktur urethra terjadi sebanyak 3 kasus $(3,1 \%)$. Hasil penelitian ini lebih rendah dibandingkan penelitian oleh Mebust et al yaitu $4 \% .{ }^{26}$ Striktur urethra dapat terjadi karena arus listrik yang digunakan selama prosedur TURP dapat mengenai urethra sehingga menimbulkan jaringan parut. ${ }^{21}$ Menurut lokasinya, striktur urethra terbagi menjadi dua jenis, yaitu striktur meatus urethra eksterna dan striktur bulbaris. Striktur meatus urethra dapat terjadi karena ukuran instrumen yang digunakan tidak sesuai dengan diameter meatus urethra, sedangkan striktur bulbar terjadi karena isolasi yang tidak cukup oleh pelumas sehingga menyebabkan arus monopolar menjadi bocor. ${ }^{11}$

Perbedaan dari insidensi komplikasi ini dapat terjadi karena dipengaruhi oleh teknik operasi, instrumen yang digunakan, serta kondisi pasien sebelum TURP, seperti pada pasien yang mengalami retensi urin akut sebelum TURP dengan volume yang tinggi (>1000 $\mathrm{ml}$ ) dapat menjadi faktor risiko sulit berkemih pascaTURP. ${ }^{11}$ Faktor-faktor yang dapat juga mempengaruhi komplikasi adalah jenis cairan irigasi yang digunakan sehingga 
menyebabkan hemolisis dan meningkatkan risiko terjadinya sindroma TUR. Cairan irigan yang ideal adalah non-elektrolit, agar tidak mengganggu arus listrik, dan iso-osmotik. Jenis cairan yang termasuk dalam kriteria tersebut adalah sorbitol 3,3\%, manitol $5 \%$, dan glisin $1,5 \%$. Cairan glisin tidak boleh diberikan kepada pasien disfungsi hati karena pemecahan glisin menghasilkan produk sampingan berupa ammonia sehingga menyebabkan hiperamonemia. Sorbitol dimetabolisme menjadi glukosa sehingga harus diberikan secara hati-hati pada pasien diabetes karena penggunaannya bisa menyebabkan hiperglikemia. ${ }^{15}$

Faktor berikutnya yang harus diperhatikan adalah identifikasi dan koreksi masalah medis pasien preoperatif. Kondisi pasien yang harus diperhatikan, antara lain jantung, ginjal, infeksi, gangguan koagulasi, dan pasien diabetes. Kondisi jantung pasien harus diperhatikan karena bisa diperberat oleh penyerapan cairan dalam volume yang besar dan komposisi elektrolit serum. Penyakit jantung menjadi salah satu penyebab kematian yang terkait dengan tindakan TURP. Pemeriksaan fungsi ginjal dengan tes kreatinin serum dan klirens kreatinin dilakukan untuk mengetahui cadangan ginjal pasien yang dapat menjaga kestabilan cairan yang berlebih. Pasien yang mengalami infeksi saluran kemih sebelum operasi harus diatasi terlebih dahulu untuk mencegah terjadinya bakterimia. Pasien dengan diabetes harus diawasi dengan ketat karena kadar glukosa serum yang tinggi dapat menyebakan meningkatnya osmolaritas serum yang dapat menyebabkan meningkatnya cairan yang diserap intravaskular dan berakibat hiponatermia yang berkaitan dengan sindroma TUR. ${ }^{15}$

\section{KESIMPULAN}

Jumlah pasien BPH yang menjalani TURP di RSUD Arifin Achmad Provinsi Riau periode tahun 2011-2015 adalah 280 pasien dengan angka kejadian komplikasi terdapat pada 93 pasien $(33,2 \%)$ dengan 105 kasus. Berdasarkan usia yang terbanyak adalah 60-69 tahun. Rerata durasi reseksi pasien adalah 30 menit. Rerata berat jaringan prostat yang direseksi (chip prostat) adalah 30 gram. Distribusi jenis komplikasi TURP terbanyak adalah perdarahan intraoperatif, jenis komplikasi intraoperatif yang terbanyak adalah perdarahan, jenis komplikasi perioperatif yang terbanyak adalah retensio urin dan jenis komplikasi lanjut yang terbanyak adalah retensio urin.

\section{DAFTAR PUSTAKA}

1. Cooperberg MR, Presti JC, Shinohara K, Carrol PR. Neoplasms of the prostate gland. In: McAninch JW, Lue TF, editors. Smith \& Tanagho's general urology. $18^{\text {th }}$ edition. New York: Mc Graw Hill; 2013. p. 350-6.

2. Parson KJ. Benign prostatic hyperplasia and male low urinary tract symptoms: Epidemiology and risk factor. PMC: 2010.

3. Girman CJ. Population-based studies of the epidemiology of benign prostatic hyperplasia. $\mathrm{Br}$ J Urol. 1998; 82 Suppl 1: 34-43.

4. Rumah Sakit Umum Daerah Arifin Achmad Propinsi Riau. Data BPH di bagian Urologi (2011-2014). Pekanbaru, 2015 [dikutip 31 Oktober 2015].

5. Shah J. Bladder outflow obstruction. In: Dawson C, Whitfield HN. ABC of urology. $2^{\text {nd }}$ edition. Singapore: Blackwell Publishing; 2006.p. 6-9.

6. Purnomo BB. Dasar-dasar urologi. Edisi kedua. Jakarta: Sagung Seto. 2012

7. Foster HE, Jacobs M. Transurethral resection of the prostate. In: McVary KT, editor. Management of benign prostatic hypertrophy. New Jersey: Humana Press; 2004.p. 163-93.

8. Bruskewitz RC. Quality of life and sexual function in patients with benign prostatic hyperplasia. RevUrol [serial on the internet]. 2003 [cited 2014 Aug 15]; 5(2): 72-80.

9. Sabri M. Gambaran pasien hyperplasia prostat jinak yang menjalani reseksi prostat transuretra di RSUD Arifin Achmad Propinsi Riau [skripsi]. Pekanbaru: Universitas Riau; 2011.

10. Chow RD. Benign prostatic hyperplasia. Patient evaluation and relief af obstructive symptoms geriatrics. 2001; 56: 33-8 [pubmed].

11.Rassweiler J, Teber D, Kuntz R, Hofmann R. Complications of transurethral resection of the prostate (TURP) - incidence, management, and prevention. Eur Urol. 2006;50: 969-80. 
12. Shrestha B, Baidhya JL. Morbidity and Early Outcome of Transurethral Resection of Prostate : A Prospective single-institute evaluation of 100 patients. Kathmandu Univ Med J [cited 2015 April 10]. Available from: http:// www.ncbi.nlm.nih.gov/pubmed/21209536

13.Mamoulakis C, Efhtimiou I, Kazoulis S, Christoulakis I, Sofras S. The modified Clavien classification system: a standardized platform for reporting complications in transurethral resection of the prostate. J Uro. 2011; 29: 205-10

14.Setiati S, Harimurti K, Govindra R. Proses menua dan implikasi kliniknya. Dalam Sudoyo AW, Setiyohadi B, Alwi I, Simadibrata M, Setiati S, editor. Buku ajar ilmu penyakit dalam, Ed.5. Jakarta: InternalPublishing;2009.757-65.

15.Sokoloff MD, Michel K, Smith RB. Complications of transurethral resection of the prostate. In: Taneja SS, editor. Complications of urologic surgery. $4^{\text {th }}$ edition. China: Saunder Elsevier; 2010.p.279-94.

16.Furuya S, Furuya R, Ogura H, Araki T, Arita T. A study of 4,031 patients of transurethral resection of the prostate performed by one surgeon: learning curve, surgical results and postoperative complications.Acta Urologica Japonica. 2006, 52(8):609-14.

17.Transurethral resection of the prostate.[cited 2015 March 10]. Available from:http:// www.hopkinsmedicine.org/healthlibrary/ t e s t transurethral_resection_of_the_prostate_turp_92,P09349/

18.Humphrey PA. Prostate. In Humphrey PA, Dehner LP, Pfeifer JD, editors. The Washington manual of surgical pathology. United States: Washington University School of Medicine; 2008.p.375-6.
19.Lynch M, Sripasad S, Subramonian K, Thompson P. Postoperative haemorrhage following transurethral resection of the prostate (TURP) and photoselective vaporization of the prostate (PVP). Ann R Coll Surg Engl. 2010 Oct; 92(7): 555-8.

20.Elisha S. Case studies in nurse anesthesia. London; 2010

21.Fajaruddin R. Faktor prognostik terjadinya komplikasi dini pada pasien pembesaran prostat jinak pasca reseksi prostat transurethral di RSUP Dr Sardjito Yogyakarta [Karya ilmiah paripurna]. Yogyakarta: Universitas Gadjah Mada; 2014.

22.Reich O, Gratzke C, Bachmann A, et al. Morbidity, mortality, and early outcome of transurethral resection of the prostate: a prospective multicenter evaluation of 10.654 patients. J Urol. 2008;180:246-9.

23.Srougi M, Antunes AA. Complications of transurethral surgery. In: Loughlin KR, editors. Complications of urologic surgery and practice. New York: Informa Healthcare; 2007.p.388.

24.Zantl N, Hartung R. TUR-related complications. In: Hohenfellner M, Santuci RA, editors. Emergencies in urology. Germany: Springer; 2007.p. 335-48.

25.Transurethral resection of the prostate. [cited 2015 March 10]. Available from: http:// www.urology-textbook.com/turp-prostateresection.html

26. Mebust WK, Holtgrewe HL, Cockett ATK, Peters PC, and Writing Committee. Transurethral prostatectomy immediate and postoperative complications:a cooperative study of 13 participating institutions evaluating 3,885 patients. J Urol 1989;141:243-7. 